\title{
Euphemism, Hedging or Mystification of Responsibility? An Investigation into Contemporary Colloquial Discourse with Particular Reference to Taxi Drivers \& Undergraduate University Students in Egypt \& Jordan
}

\author{
Ahmed Abdel Azim ElShiekh ${ }^{1}$ \\ ${ }^{1}$ Zarqa University, Jordan \\ Correspondence: Associate Professor Dr. Ahmed Abdel Azim ElShiekh, Zarqa University, 13132, Zarqa, P.O. \\ Box: 132014, Jordan (On secondment from Alexandria University, Egypt). Tel: 079-595-5838. E-mail: \\ shishuj@gmail.com
}

Received: March 28, 2013 Accepted: April 15, 2013 Online Published: May 17, 2013

doi:10.5539/ijel.v3n3p88 URL: http://dx.doi.org/10.5539/ijel.v3n3p88

This research is funded by the Deanship of Research and Graduate Studies at Zarqa University/Jordan.

\begin{abstract}
The present research attempts to investigate a certain linguistic feature which the researcher believes to be characteristic of contemporary colloquial Arabic discourse, viz. the use of certain linguistic techniques and/or tricks, whether consciously or unconsciously, to avoid the use of a harsh description of a given situation, to avoid fulfilling, answering, or performing duties and questions, or even to elude responsibility altogether. All the above-mentioned may fall under the umbrella of passivism and irresponsibility. In case this is true, academic research in the field of sociolinguistics, pragmatics and discourse analysis may as well contribute to diagnosing the phenomenon in question as a necessary step towards the solution of any problems resulting from the negative attitudes underlying the linguistic behaviour under study.

The research hypotheses stem from the researcher's personal observations in Egypt and in Jordan. In an attempt to verify these hypotheses, the present research examines a sample of common expressions used as potential and almost automatic responses to certain situations, all of which have one thing in common: dissatisfaction, ranging from the trivial or at least insignificant (Misunderstanding/Miscommunication) to the sublimely tragic (A car accident/failure in a final examination). The sample consists of two different groups: undergraduate university students and taxi drivers, in an attempt at finding out whether or not the occupational interests of the sample group members play an active role with regard to the linguistic phenomenon in question.

The researcher depends on face-to-face encounters in an attempt to keep the linguistic behaviour of the informants as fresh and spontaneous as possible. The data analysis makes use of relevant semantic, pragmatic, stylistic, grammatical and discoursal devices.

Finally, the researcher comes up with the main findings of the research, discusses them and attempts to explore the causes and possible implications of the linguistic phenomenon under study.
\end{abstract}

Keywords: euphemism, hedging, eluding, mystification, demystification, responsibility, passiveness, supernatural

\section{Introduction}

The present paper deals with some common features of human languages in general, yet with a specific reference to their phenomenal presence in contemporary colloquial discourse in Egypt and Jordan. A sample of students and taxi drivers in both countries has been selected as informants for the study.

\subsection{Significance of the Research}

Language is hardly a mere means of communicating ideas and/or feelings. The special way each one of them uses language stems from one's character, intentions and attitudes. Yet the prevailing linguistic phenomena at a particular time and in a particular place could also be of great help in exploring collective attitudes of given 
societies, local communities or even sub-communities.

Thus, the present research attempts to investigate a certain linguistic feature which the researcher believes to be characteristic of contemporary colloquial Arabic discourse, viz. the use of certain linguistic techniques and/or tricks, whether consciously or unconsciously, to avoid the use of a harsh description of a given situation, to avoid fulfilling, answering, or performing duties and questions, or even to elude responsibility altogether.

\subsection{Statement of the Problem}

Through personal observation, the researcher has noticed what seems to be a linguistic phenomenon in the way certain linguistic expressions are used to perform everyday linguistic functions within the realm of contemporary Arabic discourse over the last two decade at least, whether in Jordan or in Egypt. All the expressions in question fall under the umbrella of euphemism, hedging, eluding and total mystification of responsibility. The following question arises: does that new tendency in the linguistic behaviour of the language users in question reflect a serious corresponding attitude in their everyday behaviour and/ ideological stance? Alternatively, is it simply a matter of a linguistic fashion that is gaining prevalence?

\subsection{Scope of the Research}

For a detailed study of the phenomenon in question, an exhaustive list of all relevant expressions ought to be provided. A comprehensive analysis of such changes and their possible relation to the religious and/or ideological attitudes of the language users concerned also need to be conducted. These two requirements, however, exceed the scope of the present research.

For the purpose of the present paper, the focus will be on 6 situations where 10/11 different expressions may be used apologetically by the addressor either to create an excuse for a wrong deed/choice or to even disclaim any responsibility altogether.

\subsection{Data}

The date under study consists in six situations leading to 11 different linguistic expressions that have been chosen for the following reasons:

a) They display a variety of situations whether amongst students or taxi drivers.

b) Despite the difference in situations, the resultant linguistic expressions are all similar with regard to their basic grammatical structure; they are all declarative.

c) They are representative of more or less the linguistic functions of euphemism, hedging or mystification of responsibility and some of them have religious connotations or at least some relation with the supernatural or superstitious.

It is worth noting in this respect that even though the expressions under study may be relatively small in number, they are quite in common use and thus provide the researcher with solid data to study and analyze.

\subsection{Objectives of the Research}

The researcher aspires to test a set of hypotheses he has come up with in an attempt to analyze the phenomenon at hand. The basic objective is to find out whether the linguistic changes coincide with particular religious and/or ideological Islamist attitudes and hence, may reflect corresponding intellectual changes or not.

\subsection{Method and Tools of the Research}

Common methods employed in the study of a particular linguistic feature may include traditional descriptive linguistic methods, instrumental methods, conversation analysis, and direct methods (Ward and Al Bayyari, 2008). Nevertheless, none of these methods gives the complete picture, and the results of different methods can be forbiddingly difficult to relate to each other. In the present paper, however, the researcher used direct observation, questions and answers as his basic tools for data collection. The sample of informants consists of forty individuals; 20 Egyptians and 20 Jordanians. From each nationality, there are 10 university students as well as 10 taxi drivers. The students were chosen so as to include 5 of the first two terms and 5 among those in their final semester, with 2 top students in each of the 2 universities concerned to see if they were to react differently. All the students belonged to the Faculty of Arts, so as to exclude the factor of the possible effect of different academic studies on students' verbal responses. As for the taxi drivers in both countries, the specimen informants were picked at random, due to practical difficulties that hinder a selective choice. With regard to gender, all the drivers were, expectedly, male, whereas the ten-student specimen in both universities included five females each, three in their first year and two in their final graduation year. Religion was not a factor taken into consideration. 
Only in the case of taxi drivers, two Christians were included since most of the expressions studied had some possible religious connotations.

In most cases, the researcher depended on eliciting the reaction of the informant in a natural everyday life situation first. Interviewing the informant always came later, whether at the same situation but after the response had already taken place in a natural manner or sometimes in a separate interview in an attempt at investigating the motives underlying the linguistic response in question, particularly in the case of university students, where it was possible to have such separate interviews.

Finally, an attempt is made by the researcher at analyzing the linguistic behavior of the members of the sample in order to be able to come up with certain conclusions as to the relation between such behavior on the one hand and the attitudes of the informants, whether consciously or unconsciously motivated to produce pieces of linguistic discourse characterized by euphemism, hedging and/or total mystification of responsibility.

In addition to both word for word and communicative translations of the Arabic data, transliterations of the Arabic examples have also been provided with the introduction of each item for the first time in the research as well as in the two appendixes at the end of the paper. The transliterations are in accordance with the Romanization of Arabic in ALA-LC Romanization Tables adopted by the Library of Congress as found the following site: http://www.loc.gov/catdir/cpso/romanization/arabic.pdf. Whenever there are two different pronunciations, Egyptian and Jordanian, with just one written form, this has been indicated in the transliteration by putting the two versions next to each other. The following is an example: (nagaht/najaht or anna nagaḥt/najaht).

\section{Review of the Literature}

"It is not easy to be systematic and objective about language study" (Crystal, 1997, p. 2). Indeed, in the case of the topic of this research, with its already extremely relative nature, the task is still more difficult. To start with, however, the three terms used in the title of this research would require some snapshot at their definition: euphemism, hedging and mystification.

\subsection{Euphemism}

According to Antony Lewis in WordWeb 6.8 (2012), euphemism is "An inoffensive or indirect expression that is substituted for one that is considered offensive or too harsh". The term originated in the last quarter of the $17^{\text {th }}$ century and comes from the Greek euphemismos, from euphemos auspicious, sounding good, from eu- + pheme speech, from phanai to speak (Merriam-Webster's $11^{\text {th }}$ Collegiate Dictionary). According to Crystal (1997), euphemism is the "use of a vague or indirect expression in place of one that is unpleasant or offensive" (Crystal, 1997, p. 426). The use of euphemism is indeed common to all languages and cultures at varying degrees. "The avoidance of particular words for social reasons seems to occur in all languages and euphemisms arise in their place" (Malmkjaer, 2010, p. 241).

In fact, euphemism is quite widespread in conservative societies of which the Egyptian and Jordanian communities are typical cases in point. A classic example of euphemism in colloquial Egyptian and Jordanian is to avoid referring to cancer in everyday conversations among non-specialists by name; it is often called " المرض "الوحش" (el marad el wehesh= the bad disease) as if there were a good disease, or "المرض الخبث (el marad el

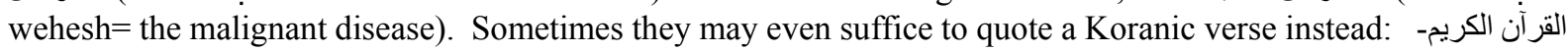
(salāmon qawlan men rabben raḥim ='Peace!' - such is the greeting, from a Lord All-compassionate- Verse 58 Sura YA SIN- Arberry, 1955), but not simply say "السرة 'ابنان" (al saratān = Cancer). Another classical though insignificant example of euphemism in both Egypt and Jordan is the refrain from using the Arabic word for black when referring to "Black pepper" but substituting the word that literally means "dark brown" instead. Thus, "، الففل الأسود، (el felfel el sewed) in many rural parts of Egypt and among some rural communities in Jordan too turns into " الفلفل الأسمر" (el felfel el asmar), just to evade the explicit mention of the colour black per se. In other words, the general tendency among Egyptians and Jordanians is not to call a spade a spade!

One has to acknowledge the universal nature of the use of euphemism in different cultures and languages and by different peoples across the ages. Yet, when it becomes a phenomenon, as the researcher believes the case in colloquial Egyptian and Jordanian discourse now, due attention should be devoted to the study of its causes, dimensions and possible implications, if not even complications.

\subsection{Hedging}

Hedging is "Any technique designed to reduce or eliminate financial risk; for example, taking two positions that will offset each other if prices change" (Lewis, 2012). The term first appeared in the $14^{\text {th }}$ century according to 
Merriam-Webster $s 11^{\text {th }}$ Collegiate Dictionary (2004). It is literally a fence or boundary formed by a dense row of shrubs or low trees, or, more generally, a means of protection or defense (as against financial loss). The term, however, is technically used in sociolinguistics and discourse analysis "to qualify or modify a statement or position so as to allow for contingencies or avoid rigid commitment a calculatedly noncommittal or evasive statement" (Merriam Webster Unabridged Dictionary Online, 2012). In more specialized references, hedging is "the expression of tentativeness and possibility, and it is central to academic writing where statements are rarely made without subjective assessments of their reliability and the need to present unproven propositions with caution and precision" (Malmkjaer, 2010, p. 6527). According to Caskey (2011), hedges are used as a strategy of holding the floor when a speaker has the floor as well as a marker of uncertainty about a statement about to be elicited (Caskey, 2011, p. 40).

The term was first introduced into the realm of linguistics by Lakoff (1973) in "Hedges: A Study in Meaning Criteria and the Logic of Fuzzy Concepts". He states that "some of the most interesting questions are raised by the study of words whose meaning implicitly involves fuzziness - words whose job is to make things fuzzier or less fuzzy. I will refer to such words as hedges" (Øvrelid, 2010, p. 4). A typical example of hedging used to bestow a tentative nature on a given statement is to use "I guess it will" instead of simply "will". Thus, I guess it will rain this afternoon $\|$ as opposed to a more declarative - It will I guess is a case in point. A more modern usage of the term from a semantic perspective would be that hedges are linguistic devices for weakening the speakers' degree of commitment to a proposition by signaling uncertainty (Palmer, 1986). A typical example of hedging in colloquial Egyptian and Jordanians could be the use of the phrase: إن شاء اله (en shāa allāh) that would mean (God willing) before any promise made by the addressor. It is not always a matter of piety, but it is often a way out for the speaker to justify never fulfilling his/her promise. The speaker or addressor is not to blame; the case is that God Almighty did not will whatever it was to happen!

\subsection{Mystification}

Mystification, which appeared as a term around 1816 and it comes from French, from mystifier to mystify, after such pairs as French falsifier to falsify: falsification ("Mystification." Webster's Third New International Dictionary, Unabridged. 2013. Web. 06 Mar. 2013). Mystification literally means an act or instance of mystifying b : an obscuring especially of capitalist or social dynamics (as by making them equivalent to natural laws) that is seen in Marxist thought as an impediment to critical consciousness the mystification of the sources of wealth (Merriam-Webster's $11^{\text {th }}$ Collegiate Dictionary). It is also explained as "when someone or something confuses you by being impossible to understand" in Cambridge Advanced Learner's Dictionary $-3^{\text {rd }}$ Edition (On CDROM). A more linguistically oriented definition would be that available on the Internet in a site labeled as the Grammar \& Composition site (http://grammar.about.com/od/mo/g/mystificationterm.htm). According to Richard Nordquist, mystification is the use of language to deceive others or to disguise the conditions of our social existence.

Distinct examples of the use mystification in the Arab world in general and the Egyptian and Jordanian societies in particular may not be as common as those of euphemism and hedging. The reason could be due to the difficulty of identifying a particular linguistic expression as a typical case of mystification out of the social context of situation. However, common phrases that are often used by the addressor when asked to document or authenticate a piece of news or rather a rumour may be fairly regarded as representative of mystification. - هم قالو قالولي - هيك قالو ا- بيقولوا - homma ālo = They said- āloly = They told me- hayk ālo = That's what they said- beyūlo $=$ They say) are all cases in point. The vague reference to the third person plural pronoun in all the previous sentences renders it impossible to evaluate the authenticity of the piece of news or information in question.

As much as the use of euphemism is quite common to different languages and cultures, Hedging is also common in political dialogue across the whole world. Politicians often resort to hedging, especially during electoral campaigns, so as to win popularity and gain more votes while, at the same time, find a way out later on to justify the non-fulfillment of their pre-elections promises. Even mystification is a common technique in the world of financial transactions to conceal one's real financial situation. Yet, when euphemism, hedging and mystification become a phenomenon in everyday discourse and among laypersons, just as the researcher believes the case is in colloquial Egyptian and Jordanian discourse now, due attention should be devoted to the study of its causes, dimensions and possible implications, if not even complications.

\section{The Research Group (Informants)}

From each nationality, there are 10 university students as well as 10 taxi drivers. The students were chosen so as to include 5 of the first two terms and 5 among those in their final semester, with 2 top students in each of the 2 universities concerned to see if they were to react differently. All the students belonged to the Faculty of Arts, so 
as to exclude the factor of the possible effect of different academic studies on students' verbal responses. As for the taxi drivers in both countries, the specimen informants were picked at random, due to practical difficulties that hinder a selective choice. With regard to gender, all the drivers were, expectedly, males, whereas the 10student specimen in both universities included five females each, three in their first year and two in their final graduation year.

In most cases, the researcher depended on eliciting the reaction of the informant in a natural everyday life situation first. Interviewing the informant always came later, whether at the same situation but after the response had already taken place in a natural manner or sometimes in a separate interview in an attempt at investigating the motives underlying the linguistic response in question, particularly in the case of university students, where it was possible to have such separate interviews.

\section{The Linguistic Functions and/or Situations under Study}

These may be divided into 2 types; trivial and serious situations, with each of the two applied to both study groups, i.e., students and drivers. All in all, 6 situations have been chosen as both authentic as well as representative of the linguistic discourse of the specimen under study with regard to euphemism, hedging and/or total mystification of responsibility. The limited number of situations investigated is due to limitations of time and space. For each expression, the researcher shall provide two translations; first, a communicative one to communicate the source language expression to English readers, and, second, a word-for-word translation that would be employed in the discussion and the data and findings analysis section.

\subsection{Trivial or Insignificant Situations}

These include linguistic functions such as reporting, commenting on or reacting to minor cases of inconvenience.

First: (Students):

Situation 1- Losing ones' pen/pencil

Arabic Expression: القلم ضاع مني (el ālam dā'menny - Both Egyptian and Jordanian)

Communicative Translation: I have lost my pen

Word for Word Translation: 'The pen got lost from me'

Situation 2- Oversleeping and hence missing the lecture

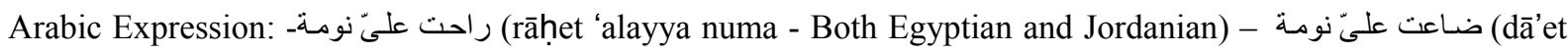
'alayya nūma - Jordanian)

Communicative Translation: I have overslept

Word for Word Translation: 'Overran me a short sleep' and 'A short sleep got lost for me'.

\section{Second (Taxi Drivers):}

Situation 1- Losing one's way/Taking the wrong road

Arabic Expressions: قدر اللهومـاشـاء فعل/الخيرة في مـا اختاره الله (qaddara allāho wa ma shāa fa'al/al khayratu fi makhtāraho allah - Both Egyptian and Jordanian)

Communicative Translations: 'God did that which He had ordained to do/God's choice is the best'.

Word for Word Translations: 'Decreed God and what He wills he does/The best (is) in that which has chosen God'.

Situation 2- Causing some delay that may result in missing an important appointment for the passenger/s.

Arabic Expressions: كل تأخيرة وفيها خيرة (koll taāira wi fīha khayra - Egyptian and Jordanian) العجلة من الثيطان (il 'ajala men il shayțān - Mainly Jordanian)

Communicative Translations: 'Haste is waste/Haste makes waste'.

Word for Word Translations: 'Every delay has in it some good/Haste is from Satan'.

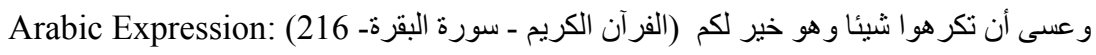

(wa 'asā ān takrahu shayān wahw khayrun lakom)

Communicative Translation: "Yet it may happen that you will hate a thing which is better for you" (The Cow. 216- Arberry, 1955).

Word for Word Translation: 'And it maybe that you hate something while it is good for you'. 


\subsection{Serious or Tragic Situations}

These include reporting, commenting on or reacting to major cases of loss and/or accidents.

First: (Students):

Situation 1- Failing an examination

Arabic Expressions: سقطوني (sāațūny -Egyptian) رسّبوني (rassabūny - Jordanian)

Communicative Translation: They failed me/They have failed me.

Word for Word Translations: 'They made me fail'.

Second: (Taxi Drivers):

Situation 1- A driver talking about/referring to a car accident he has been involved in.

Arabic Expressions: العربية عملت حادثة (il 'arabeyya 'amalet ḥādtha - Egyptian) السيارة سوّت حادثة (il sayyara sawwet ḥādtha - Jordanian)

Communicative Translation: 'I had a car accident'.

Word for Word Translation: 'The care made an accident.

\section{Findings \& Discussion}

Through direct observations made over several years, the researcher has noticed a marked tendency to resort to euphemism, hedging and even total mystification of responsibility in the linguistic expressions used by average Egyptians and/or Jordanians in a variety of everyday life situations, all of which have one thing in common: dissatisfaction, ranging from the trivial or at least insignificant (Misunderstanding/Miscommunication) to the sublimely tragic (A car accident/failure in a final examination). The items under study have been selected not only because they are authentic and quite common, but also as representative of the phenomenon in question in general. We have six situations, three related to university students and three with regard to taxi drivers. These situations cover 9 different expressions with a couple of minor differences among two of them, thus, resulting in 11 expressions as a whole. They differ as far as grammatical structures are concerned, but they certainly have one thing in common: they all reflect varying degrees of euphemism, hedging and/or mystification of responsibility. An attempt at discussing this point shall be made in the following part.

The researcher maintains that all the 11 expressions under study avoid laying any sort of blame and, hence, responsibility upon the speaker/addressor. This is done in two major ways. The first is by using an alternative grammatical structure that substitutes the object for the agent or even dismisses the agent altogether from the sentence despite the pragmatically fallacious nature of the statement. The second way lies in quoting a given proverb, wise saying or even a Koranic verse in order to shrink from responsibility or blame. To decide whether each of the 11 expressions is a case of euphemism, hedging or mystification is of a minor importance when compared with the essential question of whether the 11 expressions fall under the wide umbrella of the 3 linguistic techniques that share the property of avoiding responsibility and any subsequent consequences.

\subsection{Linguistic Structures}

This type includes the following expressions- القلم ضاع مني - (el ālam dā'menny - The pen got lost from meEgyptian and Jordanian) - (dāa'et 'alayya nūma- A short sleep got lost for me- Egyptian and Jordanian) and - ضـاعت عليَ نومة - (dā'et 'alayya numa- A short sleep got lost for me- Jordanian). The 3 previous utterances belong to the set of insignificant situations with reference to students. Two others are (sāațūny - They made me fail - Egyptian) and رسّبوني (rassabūny - They made me fail- Jordanian), both of which belong to the set of serious or tragic situations with reference to university students' discourse too. The last two items in this group are: العربية عملت حادثة حسئة (il 'arabeyya 'amalet ḥādtha - The care made an accident - Egyptian) and السيارة سوّت حادثة (il sayyara sawwet ḥādtha - The care made an accident- Jordanian), which also belong to the set of serious and/or tragic situations but are related to the discourse of taxi drivers.

The two expressions رقّبوني (rassabūny- Jordaninny- Egyptian) which both literally mean "They made me fail" are cases in point of euphemism. Instead of simply: 'I have failed/I failed' it is somebody else that deserves the blame. That somebody else is not a particular teacher or instructor; it is some sort of a vague persona; 'they'. Out of 20 students in Egypt and Jordan 16 actually used this expression while referring to a case of failing an exam, regardless of whether it is a mandatory specialization course or an elective one. The only four who did not use that expression are the four top students (2 Egyptians and 2 Jordanians) who have not been exposed to that situation during their academic life at university. Even one of the two Egyptian top students asserted that he would have likely used this expression had he ever failed an exam! As for all the rest of the 
students in the specimen, their responses were all the same; the Egyptians used سقطوني (sāattūny- They made me fail) while the Jordanians resorted to رستبوني (rassabūny- They made me fail). Age and gender had no effect. In immediate follow up discussions and/or subsequent interviews with the students, they explained that they did not have a particular teacher in mind, but that they believed they should have never failed no matter what. Only one Egyptian student and a Jordanian one literally blamed one particular instructor who, they believed, had been unfair to them. For the rest, the other 14 students, using the expressions under study was simply a means of shirking the responsibility of failure off their shoulders. The speaker/addressor is a direct object in the grammatical structure in question not an agent; it occurs in the accusative not the nominative. None of the 16 students who have once, twice or even more failed a given exam said or even claimed to have said: ' سقطت 'رسبت' (saatț or rasabt) both of which literally and communicatively mean 'I have failed' or 'I failed', and, where the pronoun referring to the addressor/speaker occurs in the nominative and functions as an agent; a doer of the action not a passive object that is acted upon. In fact, this linguistic behaviour could even be regarded as some sort of hedging as by resorting to the use of the grammatical structure under study, the speaker/addressor is declared as irresponsible for the action and hence the proposition contained in the statement. The speaker/addressor, i.e., the student that has actually failed an exam, is not responsible at all for that failure. He was unfairly failed by 'others'. Note that in case of passing exams all the members of the 10-student specimen confirmed the researcher's expectation that they would readily use the active voice and say: نحت/أنانجحت (nagaḥt/najaḥt or āna nagaḥt/najaḥt - I passed/have passed or I succeeded/have succeeded).

The other 5 expressions under this category are even clearer cases of mystification of responsibility. In each and every one of them, a certain inanimate object is personified and made the grammatical agent in a given verbal phrase in a way that renders the statement or proposition pragmatically unacceptable or at least incompatible with our knowledge of the world of external reality if literally interpreted. Instead of losing the pen, the pen gets lost! Instead of oversleeping, it is sleep that cheats me and makes me lose my lecture! Finally, it is the 'car' that causes a care accident, not the driver! In all these cases, inanimate objects or abstract concepts such as 'pen', 'car' and 'sleep' seem to have a free will and they either cause some inconvenience or even a disaster, while the human element, i.e., the speaker/addressor who has either actually lost the pen, overslept or caused a car accident, is totally mystified as in السيارة سوت حادثة / العربية عملت حادثة (The car made/caused a car accident) or at

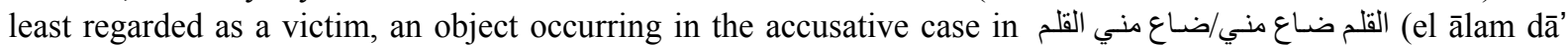
menny- The pen got lost from me) and راحت عليّ نومة/ضاعت عليَّ نومة (dā'et 'alayya numa/rā'et 'alayya nūmaOverran me a short sleep' and 'A short sleep got lost for me')! Note that in all these previous cases, there is a perfectly an alternative colloquial expression that would show the speaker/addressor as the one responsible for

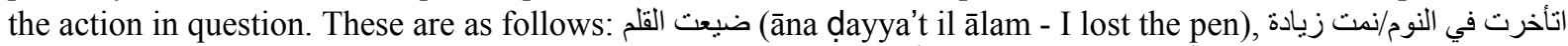
(ātākhart fil nūm/nemt zyāda - I overslept) and أنا عملت حادثة بالعربية/ أنا سويّت حادثة بالسيارة (āna 'amalt/sawwìt ḥādtha bil 'arabeyya/bil sayyara- I had a car accident)! It is also worth noting that all the informants in the specimen have either actually used the five previous expressions when exposed to the situation that stimulates its use or asserted he/she would probably use it if exposed to it. There are no exceptions here. All the specimen members, Jordanians and Egyptians alike, have responded in the same way. Age and gender did not make a difference. Thus, the use of the expressions that avoid mentioning the speaker/addressor altogether or regard such speakers as helpless objects acted upon by the inanimate objects remains a matter of choice for the language user and, hence, may be fairly indicative of an attitude underlying a certain linguistic behaviour rather than simply a random or isolated phenomenon.

\subsection{Decontextualized Quotations}

This type includes the following five expressions: قدر اللهوما شاء فعل/الخيرة في ما اختاره الهاه (Both Egyptian and Jordanian- qaddara allāho wa ma shāa fa'al/al khayratu fi makhtāraho allah) : كل تأخيرة وفيها خيرة فئارة (Egyptian and

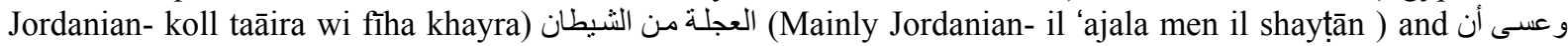
(Egyptian and Jordanian- wa 'asā ān takrahu shayān wahw khayrun lakom ), all of which fall under the category of taxi drivers' responses, both Egyptians and Jordanians.

With the exception of 'كل تأخيرة وفيها خيرة' (koll taāira wi fïha khayra) and 'العجلة من الثيطان' (il 'ajala men il shaytạn), the other three maxims/proverbs or quotations sound extremely acceptable and even axiomatic with regard to its proposition as far as the Arabic culture, in general, is concerned. Most Egyptians and Jordanians would be ready to believe that 'God did that which He had ordained to do' and that 'God's choice is the best', Muslims and Christians or even Jews alike. Certainly all Muslims would be ready to take for granted the proposition that "Yet it may happen that you will hate a thing which is better for you", especially that it is a Koranic text. Even those who are non-Muslims do not usually have a problem with the conceptual content of the statement regardless of their religious attitude towards the Koran. When the researcher asked the 2 Christian 
drivers within the specimen, an Egyptian and a Jordanian, they both responded in the same way; the Koranic nature of the quotation did not put them off. The Jordanian driver readily endorsed it, while the Egyptian one accepted it as some kind of a wise saying that does not conflict with religious beliefs.

The problem with all these three expressions simply lies in the situation the quotation or proverbial saying is used or rather misused in as well as the effect it is meant to produce. A taxi driver takes the wrong decision and, thus, causes some serious problem to the passenger by unnecessarily delaying him/her/ or losing the way. Yet, instead of taking responsibility for that, the driver dismisses the whole thing as act of God and even proceeds to demand the passenger to accept it as it may turn out to be better for him/her. After all God's choice should be regarded as the best by all believers! The climax appears with the Koranic quotation. The passenger finds himself/herself almost on the defensive; rejecting the quotation as such may sound even blasphemous! The real person in charge, the driver, is totally left out in all the five expressions. The fates seem to be at fault! Or, worse still, maybe the passenger/s should be grateful getting lost or delayed!

The other two expressions are 'العجلة من الثبطان' (il 'ajala men il shaytān- Haste is from Satan') and كل تأخيرة وفيها خيرة' ( ' koll taāira wi fỉha khayra- Every delay has in it some good/). The first one dismisses haste as an act of the devil. The proposition still sounds acceptable; after all, haste is waste in different cultures. Yet real haste is not involved here. The use of 'haste is waste' or, literally 'Haste is from Satan' is used in this context to justify losing time unnecessarily due to taking the wrong road or getting into a traffic jam while a much better road was a clearer option. The passengers in such a case are not really demanding the drivers to drive more quickly or to be hasty in any way. This is a typical case of euphemism; calling things not by their names. One might even, cynically, expect the drivers would next ask the passengers to be grateful to them for having caused them to lose an appointment or even a flight!

The most provoking of these expressions in the researcher's point of view, however, is definitely the last: كل 'تأخيرة وفيها خيرة' (koll taāira wi fîha khayra- 'Every delay has in it some good'). An over-generalized statement that defies common sense and may arouse the passenger's anger, and, yet, it was used by all the Egyptian divers in the specimen, and 8 Jordanians also said they would probably use it too, while 5 actually did. The majority of the Jordanian drivers in the specimen used the other one: العجلة من الثيطان (il 'ajala men il shaytān- Haste is from Satan), while one Jordanian driver only responded differently, using an expression that was not included by the researcher in this study, viz. الحمد اله على كل شيء (il ḥamdillāh 'ala kol shayā) which means 'Thank God for everything'. We may still note that even this response seems somewhat close to the other expressions that try to appease the offended passenger by resorting to religious sentiments.

\section{Implications and Conclusions}

In the light of the findings listed in the previous section and the discussion of the expressions under study, it may be asserted that all of them are either typical or, at least, possible examples of the techniques of euphemism, hedging, and mystification of responsibility. Hence, the researcher would like to explore the potential implications of the presence of the linguistic phenomenon in question with reference to the Egyptian and Jordanian communities.

The specimen under study is relatively small in number. Yet, the random choice of the informants, with the exception of two top students only in each university, makes it quite feasible to maintain that it is not only authentic but also quite representative. Even the deliberate choice of the four top students was meant to give a fair chance to get different responses rather than the expressions investigated. Another factor that represents an asset to the findings of the study is that the researcher has basically relied on face-to-face encounters in an attempt to keep the linguistic behaviour of the informants as fresh and spontaneous as possible. The responses elicited from the informants have matched the researcher's expectation with a $\% 100$ percent in the case of taxi drivers and $\% 90$ percent in the case of university students. The $\% 10$ percent difference is a result of the four top students who would not use the expressions under study with reference to failing an exam, simply because they have never actually had experienced it. Therefore, it may be fairly concluded that the linguistic behaviour of all the informants presents a clear-cut case of insistently refusing to bear any sort of responsibility for the events in question, attributing them to God, fates or even inanimate objects.

Now, the question arises: Could this phenomenon be simply confined to linguistic features or would it be representative of a larger general attitude and/or tendency among Egyptians and Jordanians? Is it only a matter of linguistic habits to exclude the pronoun referring to the addressor/speaker in general, or is it particularly the case when there is some blame to avoid? The researcher believes it is neither a mere linguistic feature nor just a linguistic habit. In the case of a misunderstanding or some lack of communication an The Egyptian may say: L فهمتنيش (ma fahamtenīsh - You didn't understand me) rather than يمكن أنا ما فهّمتكش (yemken ānā mafhemtaksh - 
Maybe I didn't explain myself to you). On the other hand, an average Jordanian in the same situation would also

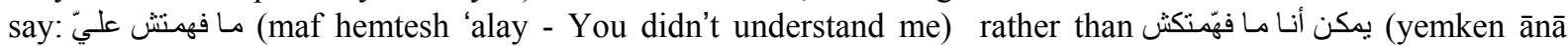
mafhemtekesh - Maybe I didn't explain myself to you). In both cases the one responsible for the lack of communication or misunderstanding is the 'other' as such, never one's self! The ego appears in the nominative though when doing so is an advantage; someone makes a mistake again and we tell him/her: ما قلت لك (ma aultelak - I have told you). Another case in point is the average Egyptian and/or Jordanian student saying: “"نجحت (nagaht/najaḥt - I succeeded/I have succeeded) on passing an exam. In this expression, the self occurs as the agent, the one that does the positive action of succeeding as such. The discrepancy is clearer when contrasted with the two common expressions attributing the students failure to the other/s per se as in the Arabic Expressions: سقطوني (rassabūny - They made me failny - They made me fail- Egyptian) Jordanian), which both mean "They failed me/They have failed me" or "I was/have been failed by them". The use of the passive voice and/or functionally equivalent Arabic structures sheds some light on the speaker/addressor's attitude. According to Bohner (2001) addressors "use the passive voice to psychologically distance themselves" (Frazer and Miller, 2009, p. 64).

The linguistic behaviour of the informants in this study is, therefore, part and parcel of a more general linguistic umbrella displaying the same features of avoiding bearing responsibility or accepting the blame for anything wrong.

If we cast a look at the general political mood in Arab societies, we may also observe the relative popularity of the conspiracy theory. Any sad events such as theory. Any sad events such as train crashes, violent demonstrations, food or fuel shortage problems or even traffic accidents are attributed to deliberate and vicious conspiracies by the enemies! For the governing regimes, the enemy is either treacherous opposition that is usually accused of collaborating with foreign powers to impose external agendas. On the other hand, the opposition too would lay all the blame on the ruling regimes. Sometimes it is even more convenient for both to start finger pointing at the Satan incarnated, i.e., USA and the little demon Israel! It has been even suggested that for several Arab regimes, especially totalitarian ones, if Israel had not existed in the region, it would have been necessary for them to create it; dictatorships and narrow-minded cultures would always welcome the presence of an external enemy to blame for all catastrophes. It is a matter of "we" and "them"; the ego is always the good one, the "other" is always the villain.

The researcher suggests the linguistic phenomenon under study is yet another manifestation of the tendency to sanctify one's self while demonising the other. The use of euphemism, hedging and all linguistic techniques of mystification of responsibility is another example of the more general and social attitude that prefers to find someone to blame while declaring themselves flawless.

The situations and expressions under study, therefore, derive more significance when examined within this more general framework. Drawing attention to the irresponsible and passive attitude underlying the linguistic phenomenon in question may help set it right. As long as we keep acting, or maybe even thinking, that all deficiencies and demerits are imposed on us and that there is nothing wrong with us at all, then there is no possibility that we can change to the better or improve our life conditions. After all, why should one improve one's self if there is nothing wrong?

In other words, the researcher hopes that through highlighting the linguistic phenomenon of euphemism, hedging and mystification of responsibility as manipulated in the expressions discussed in this research, we may be in a better position to make the average Egyptian and Jordanian citizen aware of the negative attitudes underlying its linguistic realization. Through such awareness, we may manage to start maturing, bearing our share of responsibility and, eventually, improve. In John's Gospel, we are told that "At the beginning, there was the Word"; well, let it also be the case here. Let us start with the world of words as a means to change, if not the whole world, then, at least, our Arab world.

\section{References}

English Sources

Arberry, A. J. (1955). The Koran Interpreted. UK: Penguin Books.

Brown, G., \& Yule, G. (1983). Discourse Analysis. Cambridge: Cambridge University Press. http://dx.doi.org/10.1017/CBO9780511805226

Caskey, F. (2011). Speak Like a Woman: A Corpus Linguistic and Discourse Analysis of Gendered Speech (Master's thesis). Western Carolina University. 
Cohen, A. D. (1998). Contrastive Analysis of Speech Acts: What Do We Do with the Research Findings? Studia Anglica Posnaniensia: International Review of English Studies. Adam Mickiewicz University Press.

Crystal, D. (1968). Linguistics, Language and Religion. Burns \& Oates/New York: Hawthorn Books.

Crystal, D. (1997). The Cambridge Encyclopedia of Language (2nd ed.). Cambridge University Press.

Frazer, A. K., \& Miller, M. D. (2009). Double Standards in Sentence Structure: Passive Voice in Narratives Describing Domestic Violence. Journal of Language and Social Psychology, 28(1). Sage Publications. Retrieved March 14, 2013, from Error! Hyperlink reference not valid. hosted at Error! Hyperlink reference not valid.

Grundy, P. (2000). Doing Pragmatics (2nd ed.). USA, OUP.

Halliday, M. A. K., \& Hasan, R. (1985). Language, Context and Text: Aspects of Language in a Social-Semiotic perspective. Geelong, Vic: Deakin University Press.

Holes, C. (2004). Modern Arabic: Structures, Functions, and Varieties (revised ed.). Washington, DC: Georgetown University Press.

King James Bible, John's Gospel, verse 1.

Kitis, E. (1999). On relevance again: From philosophy of language across 'Pragmatics and power' to global relevance. Journal of Pragmatics, 1999(31), 643-667. http://dx.doi.org/10.1016/S0378-2166(98)00090-3

Lakoff, G. (1973). Hedges: A study in meaning criteria and the logic of fuzzy concepts. Journal of Philosophical Logic, 2(4), 458-508. http://dx.doi.org/10.1007/BF00262952

Lewis, A. (2012). WordWeb 6.8. (Electronic Version). Antony Lewis 2012.

Library of Congress-ALA-LC Romanization Tables. Retrieved April 17, 2013, from http://www.loc.gov/catdir/cpso/romanization/arabic.pdf

Malmkjaer, K. (Ed.). (2010). The Routledge Linguistics Encyclopedia (3rd ed.). Routledge.

Merriam-Webster Unabridged Dictionary Online. Retrieved December 16, 2012, from http://unabridged.merriam-webster.com/

Merriam-Webster's Collegiate Dictionary. (2004). (11th ed.). CD Version. Merriam-Webster, Incorporated.

Øvrelid, L., Oepen, S., \& Velldal, E. (2010). Detecting and Resolving Hedges. The LNS LT-Seminar. University of Oslo.

Palmer. (1986). Mood and Modality. Cambridge Textbooks in Linguistics. Cambridge University Press. UK.

Smith, R. V. (1962). Analytical Philosophy and Religious/Theological Language. Journal of Bible and Religion, $30(2), 101-108$.

Ward, N., \& Al Bayyari, Y. (2008). A Case Study in the Identification of Prosodic Cues to Turn-Taking: BackChanneling in Arabic. Perspectives on Arabic Linguistics, XX. Retrieved February 16, 2013, from http://www.cs.utep.edu/nigel/papers/arabic.pdf

Arabic Sources

$$
\begin{aligned}
& \text { القرآن الكريم } \\
& \text { د. محمد السعيد بدوي (1978). مستويات العربية المعاصرة في مصر. دار المعارف. }
\end{aligned}
$$

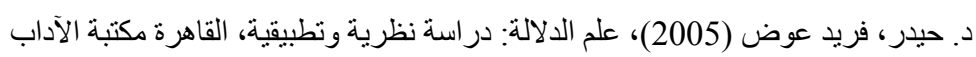

\section{Appendices}

Appendix 1. University Students

\begin{tabular}{|c|c|c|c|c|c|c|}
\hline Expression & $\begin{array}{c}\text { Transliteration } \\
\text { and Word for } \\
\text { Word } \\
\text { Translation }\end{array}$ & $\begin{array}{c}\text { Frequency } \\
\text { of Use in } \\
\text { Egypt }\end{array}$ & $\begin{array}{c}\text { Frequency } \\
\text { of Use in } \\
\text { Jordan }\end{array}$ & Total & $\begin{array}{c}\text { Type of } \\
\text { Expression }\end{array}$ & $\begin{array}{c}\text { Additional } \\
\text { Remarks }\end{array}$ \\
\hline $\begin{array}{c}\text { el ālam dā' } \\
\text { menny-The pen } \\
\text { got lost from me }\end{array}$ & 10 & 10 & 20 & $\begin{array}{c}\text { Linguistic } \\
\text { Structures }\end{array}$ & \\
\hline
\end{tabular}




\begin{tabular}{|c|c|c|c|c|c|c|}
\hline ضاعت علىَ & $\begin{array}{c}\text { dā'et 'alayya } \\
\text { numa- A short } \\
\text { sleep got lost for } \\
\text { me }\end{array}$ & 10 & 7 & & $\begin{array}{l}\text { Linguistic } \\
\text { Structures }\end{array}$ & \multirow{2}{*}{$\begin{array}{l}\text { These two } \\
\text { structures are } \\
\text { grammatically } \\
\text { and semantically } \\
\text { identical- The } \\
\text { difference is } \\
\text { confined to one } \\
\text { partial synonym }\end{array}$} \\
\hline راحت علىّ نومة & $\begin{array}{c}\text { rā'et 'alayya } \\
\text { nūma- Overran } \\
\text { me a short sleep }\end{array}$ & 0 & 3 & 20 & $\begin{array}{l}\text { Linguistic } \\
\text { Structures }\end{array}$ & \\
\hline رسّبوني & $\begin{array}{l}\text { rassabūny- They } \\
\text { made me fail }\end{array}$ & 0 & 8 & & $\begin{array}{l}\text { Linguistic } \\
\text { Structures }\end{array}$ & \multirow{2}{*}{$\begin{array}{l}\text { These two } \\
\text { structures are } \\
\text { grammatically } \\
\text { and semantically } \\
\text { identical- The } \\
\text { difference is } \\
\text { confined to one } \\
\text { partial synonym }\end{array}$} \\
\hline سقطوني & $\begin{array}{l}\text { sāatūny- They } \\
\text { made me fail }\end{array}$ & 8 & 0 & 16 & $\begin{array}{l}\text { Linguistic } \\
\text { Structures }\end{array}$ & \\
\hline
\end{tabular}

\section{Appendix 2. Taxi Drivers}

\begin{tabular}{|c|c|c|c|c|c|c|}
\hline Expression & $\begin{array}{c}\text { Transliteration } \\
\text { and Word for } \\
\text { Word } \\
\text { Translation }\end{array}$ & $\begin{array}{c}\text { Frequency } \\
\text { of Use in } \\
\text { Egypt }\end{array}$ & $\begin{array}{l}\text { Frequency } \\
\text { of Use in } \\
\text { Jordan }\end{array}$ & Total & $\begin{array}{c}\text { Type of } \\
\text { Expression }\end{array}$ & $\begin{array}{l}\text { Additional } \\
\text { Remarks }\end{array}$ \\
\hline قدر الله وما شاء & $\begin{array}{c}\text { qaddara allāho } \\
\text { wa ma shāa fa'al- } \\
\text { Decreed God and } \\
\text { what He wills he } \\
\text { does }\end{array}$ & 10 & 10 & 20 & $\begin{array}{c}\text { Decontextual } \\
\text { ized } \\
\text { Quotations }\end{array}$ & $\begin{array}{c}\text { Alternative } \\
\text { Religious } \\
\text { connotations }\end{array}$ \\
\hline الختيرة في ما آله & $\begin{array}{l}\text { al khayratu fi } \\
\text { makhtāraho } \\
\text { allah- The best } \\
\text { (is) in that which } \\
\text { has chosen God. }\end{array}$ & 10 & 10 & 20 & $\begin{array}{c}\text { Decontextual } \\
\text { ized } \\
\text { Quotations }\end{array}$ & $\begin{array}{l}\text { Alternative } \\
\text { Religious } \\
\text { connotations }\end{array}$ \\
\hline الثجلة من & $\begin{array}{l}\text { il 'ajala men il } \\
\text { shayțān- Haste is } \\
\text { from Satan' }\end{array}$ & 10 & 9 & 19 & $\begin{array}{c}\text { Decontextual } \\
\text { ized } \\
\text { Quotations }\end{array}$ & $\begin{array}{c}\text { Alternative } \\
\text { Religious } \\
\text { connotations }\end{array}$ \\
\hline كل تأخيرة وفيها & $\begin{array}{l}\text { koll taāira wi } \\
\text { fîha khayra- } \\
\text { Every delay has } \\
\text { in it some good }\end{array}$ & 10 & 5 & 15 & $\begin{array}{l}\text { Decontextual } \\
\text { ized } \\
\text { Quotations }\end{array}$ & \\
\hline وتكر هو أشيَّا & $\begin{array}{c}\text { wa 'asā ān } \\
\text { takrahu shayān } \\
\text { wahw khayrun } \\
\text { lakom- It maybe } \\
\text { that you hate } \\
\text { something while } \\
\text { it is good for you }\end{array}$ & 9 & 10 & 19 & $\begin{array}{c}\text { Decontextual } \\
\text { ized } \\
\text { Quotations }\end{array}$ & $\begin{array}{l}\text { A Koranic } \\
\text { quotation }\end{array}$ \\
\hline السيارة سوّت & $\begin{array}{l}\text { il sayyara } \\
\text { sawwet ḥādtha- } \\
\text { The care made } \\
\text { an accident }\end{array}$ & 0 & 10 & & $\begin{array}{l}\text { Linguistic } \\
\text { Structures }\end{array}$ & $\begin{array}{c}\text { These two } \\
\text { structures are } \\
\text { grammatically } \\
\text { And even }\end{array}$ \\
\hline
\end{tabular}




\begin{tabular}{|c|c|c|c|c|c|c|}
\hline $\begin{array}{c}\text { العربية عملت } \\
\text { حادثة }\end{array}$ & $\begin{array}{c}\text { il 'arabeyya } \\
\text { 'amalet hāātha } \\
\text {-The care made } \\
\text { an accident }\end{array}$ & 10 & 0 & 20 & $\begin{array}{c}\text { Linguistic } \\
\text { Structures }\end{array}$ & $\begin{array}{c}\text { semantically } \\
\text { identical- The } \\
\text { difference is } \\
\text { confined to one } \\
\text { partial synonym }\end{array}$ \\
\hline
\end{tabular}

